\title{
Food Security Dynamics and Its Drivers in Rural Mozambique
}

\section{Raul Pitoro' 1 , Takemore Chagomoka²}

\author{
${ }^{1}$ Department of Agricultural, Food, and Resource Economics, Michigan State University, East Lansing, MI-USA \\ 48824 \\ ${ }^{2}$ World Vegetable Center-West and Central Africa, Bamako, Mali
}

\begin{abstract}
This paper uses regionally representative panel household survey data of 1,186 households in the high agriculture potential zone located in the Central and Northern regions to assess household food security trends and its drivers, specifically to determine the extent landholdings have influenced food security dynamics in rural Northern-Central Mozambique. The main finding of this study is that although food security level has been stable over the study period, the agricultural production, rural non-farm activities, establishment of food reserves, food availability, assets, and access to non-farm income opportunities and transportation have influenced food security level of the rural families. This suggests that investing in infrastructures such as public transportation and roads, minimizing agricultural production risks, promoting in education and livestock production aremore likely to have a larger effect on the extremely poor households than on the less poor when wage employment opportunities and proper training are available.
\end{abstract}

Keywords: Food Security, Landholdings, Mozambique, Panel Data, Rural, Dynamics

\section{Introduction}

Poverty, hunger, and malnutrition are three main constraints affecting the livelihoods of human beings in most parts of the worlds. In developing countries these are an important cause of child mortality and the governments in developing countries such as Mozambique have long struggled to defeat hunger [1]. In the context of Mozambique, this situation is surprising as it contradicts the economic growth that is being observed as a result of government efforts in implementing a set of development programs and policies including the National Action Plan for the Reduction of Absolute Poverty. The government of Mozambique has committed to reducing poverty from 70 percent in 1997 to 40 percent by 2015 through several interventions to reduce poverty and food insecurity, such as: the construction of silos with 50,000 metric ton capacity for grain storage in Tete province, improvement of infrastructure such as the construction of the bridge across Zambezi river which links the main production areas to consumption areas [2] and increasing agriculture production. All these interventions witness an impressive economic growth which shows a GDP growth of more than 6.3 percent per year since 2006 [3].

\begin{abstract}
Despite all this impressive growth, poverty has not been falling as intended as judged by the ranking in some macroeconomic indicators such as being $180^{\text {th }}$ of 188 on the 2015 UNDP Human Development Index and $64^{\text {th }}$ out of 78 on the 2013 Global Hunger Index [4, 5, 7]. As reported by [6], food security continues to be rampant in Mozambique, with estimates of up to 24 percent of the population remain chronically food insecure, and a chronic malnutrition in children under five remaining high at 44 percent, vitamin A, and iron deficiency in children under 5 is high reaching 69 and 74 percent respectively. This scenario is exacerbated by cyclical climatic disasters (floods and droughts) and food price crisis in 2008 leaving no other option to the government but to engage in food aid to meet domestic needs.
\end{abstract}

On the other hand, food security docummentation in Mozambique is mostly based on cross-sectional analysis [1, 7, 2, 9], studies that have systematically used the existent panel data to assess the routes out of food insecurity which is of important interest for policymakers, development practitioners are scant. These limitations have motivate this paper, which aims to assess pathways out food insecurity identifying the major "push" and "pull" forces into or

This article is published under the terms of the Creative Commons Attribution License 4.0

Author(s) retain the copyright of this article. Publication rights with Alkhaer Publications.

Published at: http://www.ijsciences.com/pub/issue/2017-05/

DOI: 10.18483/ijSci.1266; Online ISSN: 2305-3925; Print ISSN: 2410-4477 
out of food insecurity with especial attention to landholdings. We focus on landholdings because it is belied that the most prominent cause of malnutrition and poverty is the land scarcity [9] and as argued by [10], access to land has a positive effect on poor people, particularly regarding food security. More specifically, this study aims to address three main questions: (i) how food security level changed over time? (ii) what determined those changes, specifically to what extent landholdings have influenced these changes? (iii) How does land access affect the pathways out of food insecurity? Finally, finding answers, the above questions will allow drawing policy implications as to address poverty reduction in rural Mozambique. The main hypothesis to be tested is food price crises could have created incentives to reverse the actual downward land access trend to produce more food and increase income.

\section{Data and Methods}

\subsection{Data description}

We use data from a repeat household agricultural survey regionally representative conducted by the Mozambique Ministry of Agriculture covering the period before and after the food price crises, in 2008 and 2011. A sample of 1,186 households were surveyed in the Central and Northern regions in the five provinces with high agricultural potential (Manica, Tete, Sofala, Nampula, and Zambezia). Before delving into estimation approach, some considerations need to be made concerning the data. First, we used the Inverse Probability Weights are used to control for the attrition bias following [11] due to financial reasons and refusal or unavailability of the respondents and households that have moved, or dissolved (see [12] for more detail). Second, out of 72 districts sampled in 2008, 42 districts were not revisited in 2011 in Zambezia, Manica, Tete, and Sofala provinces therefore, no longer representative at the provincial level in these provinces, while representative in Nampula province as is the only one that did not drop a district between the two survey years.

\subsection{Estimation strategy \\ 2.2.1 Defining and measuring food security}

The concept of food security has been a center of heated debates and improvements since the mid1970's $[13,14,15,16,17,18]$. In this paper, we define food security as social, economic and physical access to meet the food needs and preferences at desired quality and quantity at all times to all people. This definition is intended to incorporate the four main dimensions of food security: (i) availability, (ii) access (iii), utilization, and (iv) stability.

Various measurement approaches have been developed for this concept, and the most commonly used approaches are consumption and expenditure, nutritional status, resource-related correlations, coping strategies and the food balance as suggested by [19]. Although the consumption/expenditurebased measures have been largely used in the empirical research to estimate the food security status, they have their flaws. For instance, do not take into account the vulnerability and sustainability elements of food security nor indicate in which type of diet (quality vs. quantity issue); therefore, none of the methods have been accepted as a "gold standard" to measure food security [20]; suggesting the need for more integrated measure.

In Mozambique, various attempts to measure food security in empirical research have been made, such as: food expenditures as a proxy for food security by [1, 21], food sufficiency [22], food consumption score (FCS), the coping strategy index (CSI), and household dietary diversity score by [23], and the amount of calories obtained by each household as compared to its needs [2].

In this study, we adopted a subjective measure of food security due to data limitation and to address both vulnerability and sustainability issues overlooked using above measures. We used the households' perception on food sufficiency to meet their members' needs as an indicator that incorporates both vulnerability and sustainability elements. With this subjective measure, we aim to capture both aspects of the definition of food security (availability, access, utilization, and stability) and incorporate the individual perceptions derived from a bottom-up definition which is often missed by topdown measures. We measured food insecurity based on the household reporting "whether it had enough food to meet its members' needs". Then, for the empirical analysis, the subjective food security measure is defined as a binary variable where a one is assigned to households is classified as food insecure, those experienced periods without enough food to feed its members, and zero otherwise (for those considered food secure.Again, like any other measure, this indicator is not free of limitations, including the fact that not having enough food to meet family does not necessarily implies that all household members have experienced food insecurity. Also, the perceived food insecurity during the survey period could have been transitory.

\subsubsection{Food Insecurity Model}

To construct food insecurity indicator, the latent variable $Y^{*}$ will be defined as:

$Y^{*}=$ food $^{i s}=\left\{\begin{array}{l}1 \text { if } \Psi_{\mathrm{it}}<\text { food }_{i t}^{r e q} \\ 0 \text { Otherwise }\end{array}\right.$ 
where $\Psi_{i t}$ is the perceived food available in household $i$ in time $\mathrm{t}$ and food ${ }^{\text {req }}$ is perceived household food needs. The estimation of food insecurity determinants will be implemented through a class of Probit models estimated as follows:

$$
\operatorname{Pr}\left(\text { food }^{\mathrm{is}}{ }_{i t}=1 \mid X\right)=\delta\left(X^{\prime}{ }_{i t} \beta\right)
$$

where $\delta$ is the standard normal cumulative distribution function, $X$ a vector of drivers of food security which include technology adoption; farm size; demographics (household size, gender of the head, education); wealth; food reserves and coping strategies; off-farm work; aggregated agricultural production; economic conditions; and access to public services; and $\beta$ is a vector of coefficients to be estimated by maximum likelihood. More specifically, the food security model is expressed as follows:

$$
\text { food }_{i t}^{i s}=\beta_{0}+\beta_{1} \text { Land }_{i t}+\beta_{2} X_{i t}+c_{i}+\varepsilon_{i t} ; t=1, \ldots, T
$$

Where Land $_{i t}$ is land per AE (ha), $X_{i t}$ a vector of other food security drivers, $t$ measures time differences (1 for 2011), and $\varepsilon_{i t}$ is the idiosyncratic error term. To capture the differences in agricultural production potential and other regional fixed-effects, district dummy variables were included in the model. The parameter of interest is $\beta_{1}$, which tests whether changes in land size have an effect on the food security. Given that the coefficient estimates of Probit models are not easily interpretable, we estimated and reported the marginal probability effects of the covariates.

\subsubsection{Modelling Food Insecurity Pathways}

The estimation strategy consists of five main steps: First, based on their food security status in each year, we classified households into four mutually exclusive food security groups.

(a) Movers: those who were food insecure in 2008 and exit from it in 2011.

(b) Entrants: those who were food secure in 2008 but became food insecure in 2011.

(c) Chronic food insecure: those who were found in food insecurity trap in both years

(d) Always food secure: those who remained food secure in both years

Second, the forces pulling into or pushing out of food insecurity were found by estimating the following multivariate regression:

$$
P_{i j}=\beta_{0}+\beta_{1} \text { Land }_{i 08}+\beta_{2} X_{i 08}+\varepsilon_{i 08}
$$

where $P_{i j}$ is the probability of being in one group $j$ (e.g. become food insecure compared to those who were always food secure or become food secure compared to those who were always food insecure),
Land represent landholdings per adult equivalent, $X$ other covariates including: characteristics of the household head, household demographics, household human capital, sector of economic activity, areas of household agricultural activity, habitation, and fixed location effects (represented by dummy variables). The last term $\varepsilon$ represents a residual error term that is assumed to be identically distributed and independent of the explanatory variables. The dependent variable takes one of the four discrete indicators indicating the food security status of the household. While some explanatory variables are included in the model, the focus is on landholdings. As the goal is to analyze to what extent the initial endowments might affect the food security of the households over time, the 2008 values (08 subscript) of the explanatory variables are used in the regressions.

Essentially, this model tries to estimate the structural reasons for transitions as it estimates the number of assets (land) that needed to explain the observed transition from one status to another. Rejecting the null that their assets are expected to meet household's food needs denotes transitory food insecurity while failing to reject is interpreted as structural food insecurity. The latter is of most importance for policy design as it represents chronic food insecurity.

To assess the consistency of our results, a robustness check is performed where we use the availability of food within the family as a proxy for food sufficiency, which we believe to be positively correlated with food security. For the robustness check, we classify households into self-sufficient if they reported seven or more months of food reserves during 12 months before the interview. A binary variable was created with a value of one assigned to self-sufficient households and zero otherwise.

\subsubsection{Hypothesized drivers of household food insecurity}

Food security is a multifaceted concept and, therefore, it is expected to be affected by a multiplicity of factors. At the aggregate level, the principal factors thatinfluence food securityinclude soil fertility, climatic extremes, disease epidemics, business or electoral cycles, civil unrest and disasters [24]. The climate variability causes crop failures, livestock die-offs, and natural disasters; disease epidemics among crops, livestock, or humans causing dramatic in incomes while increasing expenditures to treat disease. The business cycle troughs increase unemployment and, therefore, reduce workers' purchasing power. All this seems to suggest that, food insecurity is not necessarily a failure of agricultureinproducing sufficient food; rather, it results from a failure to provide local livelihood opportunities to access food beyond agricultural 
production [25, 26, 27]. To mitigate such adversities, people pursue a range of livelihood strategies to increase their income and asset base, spread or reduce risk, mitigate the impact of shocks, and ensure survival [27].

Food security also depends on socio-economic conditions, including the distribution, access, and affordability of food; political and natural environment; the performance of the food economy; and household-level factors. At the household level, food security is affected by the household's livelihood, defined as the combined assets, activities, and capabilities that contribute to the household's existence [28].

With notion of complex web of food security drivers, we then, hypothesize that food securityis negatively associated with dependence ratio as shown by [29] that the dependence ratio is relatively high in food insecure households given the fact large households with less economically active members result in increased nutritional needs that the household cannot afford, resulting in increased food insecurity.

To capture gender earning differences in rural Mozambique, we hypothesizing that female-headed households are disadvantaged in both income and food security, and therefore, female-headed households are more likely to be poor and food insecure than male-headed households as found elsewhere by [30, 2].

The civil status of the head is expected to have a significant effect on food insecurity. We expect households headed by widows to be more food insecure and limited income if they do not have strong social ties and resource savings from their deceased partners. However, if they can benefit from social services, they can be food secure.

We also included some variables to capture physical capital variation in rural Mozambique, such as farmland, housing quality, soil quality, and income sources which are expected to be positively correlated with income and food security in rural Mozambique because such productive physical capital makes a significant contribution to reducing poverty. Soil quality is included as a covariate in our models because good soil quality is associated with high productivity and production expected to raise incomes or food availability within the family. Therefore, a positive on income models and negative on food insecurity models are expected. Since livestock is perceived as an important asset and indicator of wealth in rural Mozambique, we used total tropical livestock units expected to have a positive effect on food security.
Better access to infrastructures is expected to have a positive impact on food security. To capture this effect, we derived a proxy for remoteness as a binary variable with one assigned to households living in the villages with access to public transportation services throughout the year and zero otherwise.

Access to extension services, credit, and technology adoption are expected to reduce food insecurity in the study area assuming that these services are available at the right time, quantity and quality. While access to credit is expected to smooth food consumption, the technology adoption is expected to reduce food security through increased incomes and food availability through crop production. The technology adoption measured as the use of high-yielding varieties of the main staple foods along with the improved agronomic practices (defined as binary variable with value of one for those using improved production technologies and zero otherwise and crop production) and crop production, defined as aggregated crop production into wheat equivalents are both expected to have positive effect on food security.

\section{Results and Discussion}

As we aim at estimating the relationship between landholdings and food security, the results in Table 1 show that landholdings are positively associated with moving out food insecurity and other analysis showing higher proportion of food insecure the households in the bottom landholdings quintile than those in top quintiles using two different measures of food security. As reported in Table 1, in addition to landholdings, escaping food insecurity is related with the availability of food reserves, food production, livestock production, and income. Food insecurity appears to be increasing with household size.

Escaping food insecurity is found to be positively associated with access to infrastructures (roads and transport) and male-headship, while negatively related to dependence ratio and widow-headship. Results also show that households that were food secure over the study period are better off in terms of asset ownership (livestock), access to credit, agricultural technology use, access to non-farm income opportunities, and food reserves from own production compared to those that became food insecure from 2008 to 2011. On the other hand, household that became food insecure during the period of study, have observed limited food reserves from their own production due to loss of production and low production as compared to those that remained food secure all along. We then, explore these findings empirically in the next sections. 
Table 1: Characteristics of sampled households

\begin{tabular}{|c|c|c|c|c|c|c|c|c|c|c|}
\hline \multirow[t]{3}{*}{ Characteristics } & \multicolumn{2}{|c|}{ Year } & \multirow[t]{3}{*}{ Total } & \multicolumn{4}{|c|}{ Poverty transition groups } & \multirow{2}{*}{\multicolumn{3}{|c|}{$\begin{array}{l}\text { Significance of men } \\
\text { differences }\end{array}$}} \\
\hline & \multirow{2}{*}{$\begin{array}{c}2008 \\
\mathrm{~A} \\
\end{array}$} & \multirow{2}{*}{$\begin{array}{c}2011 \\
\text { B } \\
\end{array}$} & & \multirow{2}{*}{$\frac{\text { Movers }}{\mathrm{C}}$} & \multirow{2}{*}{$\begin{array}{c}\begin{array}{c}\text { Always food } \\
\text { insecure }\end{array} \\
\text { D } \\
\end{array}$} & \multirow{2}{*}{$\begin{array}{c}\text { Entrants } \\
\mathrm{E}\end{array}$} & \multirow{2}{*}{$\begin{array}{c}\begin{array}{c}\text { Always } \\
\text { food secure }\end{array} \\
\text { F } \\
\end{array}$} & & & \\
\hline & & & & & & & & {$[\mathrm{A}-\mathrm{B}]$} & [C-D] & {$[\mathrm{E}-\mathrm{F}]$} \\
\hline Household physical capital & & & & & & & & & & \\
\hline Cultivated area per $\mathrm{AE}(\mathrm{ha})$ & 0.7 & 0.6 & 0.7 & 0.6 & 0.4 & 0.6 & 0.7 & & * & \\
\hline Total area owned per $\mathrm{AE}(\mathrm{ha})$ & 0.8 & 0.8 & 0.8 & 0.7 & 0.5 & 0.7 & 0.9 & & * & * \\
\hline HHs with good land quality (\%) & 34.3 & 36.0 & 35.2 & 29.2 & 27.8 & 33.8 & 38.0 & & & * \\
\hline $\mathrm{HH}$ concerned about future land conflict (\%) & 100.0 & 5.2 & 52.7 & 54.8 & 54.2 & 52.1 & 52.2 & & & \\
\hline HH Net income per AE (in '000 2011 Meticais) & 10.7 & 8.2 & 9.4 & 1.2 & 5.9 & 6.9 & 9.9 & & & \\
\hline Total Tropical Livestock units per $\mathrm{HH}$ & 1.0 & 0.9 & 0.9 & 0.6 & 0.5 & 0.6 & 1.2 & & & $* *$ \\
\hline Aggregated crop production (' $000 \mathrm{Kgs}$ of wheat equivalent) & 1.6 & 3.3 & 2.4 & 1.6 & 0.8 & 1.0 & 3.2 & ** & & \\
\hline HH have good quality housing walls (\%) & 10.5 & 10.1 & 10.3 & 7.8 & 4.8 & 6.5 & 12.6 & & * & ** \\
\hline House human capital & & & & & & & & & & \\
\hline Male-headed $\mathrm{HH}(\%)$ & 82.1 & 81.5 & 81.8 & 80.6 & 66.7 & 75.8 & 85.7 & & ** & ** \\
\hline HH head is a widow (\%) & 7.2 & 7.0 & 7.1 & 8.9 & 13.0 & 8.2 & 5.6 & & $*$ & ** \\
\hline Head's age (Years) & 42.4 & 42.2 & 42.3 & 41.4 & 41.9 & 41.9 & 42.6 & & & \\
\hline People aged $15-59$ years (Number) & 2.6 & 2.6 & 2.6 & 2.7 & 2.5 & 2.6 & 2.6 & & & \\
\hline Dependence ratio & 1.4 & 1.4 & 1.4 & 1.4 & 1.7 & 1.5 & 1.3 & & * & $*$ \\
\hline People with self-employment in the HH (Number) & 0.7 & 0.6 & 0.7 & 0.6 & 0.6 & 0.7 & 0.7 & $*$ & & \\
\hline HHs that participated in off-farm jobs (\%) & 37.7 & 38.1 & 37.9 & 42.9 & 46.9 & 36.9 & 35.7 & & & \\
\hline Males in secondary school (Number) & 0.2 & 0.2 & 0.2 & 0.2 & 0.1 & 0.1 & 0.2 & & & $* *$ \\
\hline Females in secondary school (Number) & 0.1 & 0.1 & 0.1 & 0.1 & 0.1 & 0.1 & 0.1 & & & \\
\hline HH head's main activity: & & & & & & & & & & \\
\hline Agriculture as main activity of the head (\%) & 44.5 & 49.1 & 46.8 & 45.8 & 56.3 & 48.4 & 45.3 & & & \\
\hline Head engage in agricultural as second activity (\%) & 16.1 & 14.5 & 15.3 & 14.9 & 8.6 & 14.6 & 16.5 & * & & \\
\hline Head not engage in agricultural activities (\%) & 33.0 & 28.8 & 30.9 & 31.0 & 27.9 & 26.4 & 32.4 & & & $*$ \\
\hline Head engaged in other activities (\%) & 6.4 & 7.6 & 7.0 & 8.4 & 7.2 & 10.5 & 5.8 & * & & $* *$ \\
\hline Household access to services and infrastructure & & & & & & & & & & \\
\hline HH leaving in non-remote villages (\%) & 40.8 & 42.5 & 41.7 & 33.1 & 42.0 & 39.5 & 44.3 & & ** & \\
\hline $\mathrm{HH}$ received credit $(\%)$ & 3.1 & 4.9 & 4.0 & 3.4 & 1.6 & 2.7 & 4.8 & & & ** \\
\hline HH have access to extension services (\%) & 13.2 & 14.0 & 13.6 & 16.3 & 16.7 & 14.7 & 12.3 & & & \\
\hline HH used pesticide (\%) & 2.5 & 2.2 & 2.4 & 1.9 & 0.2 & 2.7 & 2.7 & & & \\
\hline HH hired permanent labor (\%) & 5.1 & 4.8 & 5.0 & 3.2 & 1.2 & 1.8 & 6.7 & & & ** \\
\hline HH hired seasonal labor (\%) & 26.2 & 27.9 & 27.0 & 23.5 & 9.9 & 17.9 & 32.5 & & & $* *$ \\
\hline HH use animal traction (\%) & 12.1 & 10.4 & 11.2 & 9.7 & 7.3 & 9.7 & 12.5 & & & $* *$ \\
\hline
\end{tabular}

\begin{tabular}{|c|c|c|c|c|c|c|c|c|c|c|}
\hline \multirow[t]{3}{*}{ Characteristics } & \multicolumn{2}{|c|}{ Year } & \multirow[t]{3}{*}{ Total } & \multicolumn{4}{|c|}{ Poverty transition groups } & \multirow{2}{*}{\multicolumn{3}{|c|}{$\begin{array}{l}\text { Significance of men } \\
\text { differences }\end{array}$}} \\
\hline & \multirow{2}{*}{$\frac{2008}{\mathrm{~A}}$} & \multirow{2}{*}{$\begin{array}{c}2011 \\
\text { B } \\
\end{array}$} & & \multirow{2}{*}{$\begin{array}{c}\text { Movers } \\
\mathrm{C} \\
\end{array}$} & \multirow{2}{*}{$\begin{array}{c}\begin{array}{c}\text { Always food } \\
\text { insecure }\end{array} \\
\text { D } \\
\end{array}$} & \multirow{2}{*}{$\begin{array}{c}\text { Entrants } \\
\mathrm{E}\end{array}$} & \multirow{2}{*}{$\begin{array}{c}\begin{array}{c}\text { Always } \\
\text { food secure }\end{array} \\
\text { F } \\
\end{array}$} & & & \\
\hline & & & & & & & & {$[\mathrm{A}-\mathrm{B}]$} & [C-D] & [E-F] \\
\hline \multicolumn{11}{|l|}{ Household coping strategies } \\
\hline Food reserves of the most important staples (Months) & 7.3 & 7.2 & 7.3 & 6.4 & 4.6 & 6.4 & 8.1 & & ** & ** \\
\hline Meals taken by the HH during hungry seas on (Number) & 15.3 & 12.3 & 13.8 & 15.8 & 36.8 & 18.6 & 9.0 & ** & ** & $* *$ \\
\hline HH purchased cassava in the last 30 days (\%) & 11.4 & 13.5 & 12.4 & 10.5 & 13.6 & 10.6 & 13.2 & & & \\
\hline $\mathrm{HH}$ purchased grain maize in the 30 days (\%) & 26.7 & 24.6 & 25.7 & 34.1 & 47.1 & 31.3 & 19.2 & & ** & ** \\
\hline \multicolumn{11}{|l|}{ HH's food reserves from own production food access: } \\
\hline Yes & 84.6 & 84.6 & 84.6 & 79.1 & 72.6 & 80.2 & 88.7 & & & $* *$ \\
\hline No, because did not grow crops & 5.6 & 5.3 & 5.4 & 4.7 & 8.6 & 4.8 & 5.3 & & & \\
\hline No, because lost production & 4.4 & 5.1 & 4.8 & 8.6 & 10.1 & 6.7 & 2.6 & & & ** \\
\hline No, because had low production & 5.4 & 5.0 & 5.2 & 7.5 & 8.7 & 8.3 & 3.4 & ${ }^{*}$ & & $8 *$ \\
\hline Observations & 1,172 & 1,172 & 2,344 & 376 & 202 & 364 & 1,402 & & & \\
\hline
\end{tabular}




\subsection{Determinants of household food insecurity}

Table 2 presents results of food security dynamics between 2008 and 2011. The models fit the data relatively well and most estimated coefficients have expected signs and consistent with our expectations as well as with relevant literature $[1,2,7$, $10]$,).Results show that a 1 percent increase on each of the two measures landholdings (cultivated and total landholdings) reduces the likelihood of the household being food insecure by about 3 percent while the concern of future land conflicts increases food insecurity by about 5 percentage points.

The availability and access to food are correlated with household food security as assessed by the positive and significant effect on crop production and food reserves on food security. An additional 1 percent of crop production and one month of food reserves are associated with a decrease in food insecurity by 2 percent and 3 percent, respectively.

Consistent with previous poverty studies in Mozambique by [31, 32, 33, 2], our results indicate that male-headed, non-widow-headed households and additional male members with secondary school of education decreases the likelihood of being food insecure by 8 percent, 7 percent, and 6 percent; respectively. As for the household size, our results show that increasing household size does not have significant effect on food insecurity, but most importantly, the increasing the dependence ratio increases the chance of a household being food insecure by 9 percent to as much as 16 percent. These results suggest that food security deteriorates when the ability to generate income within the household is limited.

The possession of assets has shown being an important driver in reducing food insecurity. Our estimation included used good housing quality (housing with good walls) and livestock possession in addition to operated land size. Our results indicate that households that possess good housing (good walls) tend to be 8 percentage points less likely to be food insecure than their counterparts with poor housing.

The participation in income generating activities is proving to be important to escape food insecurity. An additional 1 percent of income decreases the likelihood of being food insecure by about 1-2 percent. This suggests the importance of both monetary and asset-based measure of poverty as an important indicator for decision-making in targeting food security programs.

Access to off-farm opportunities was found to reduce the propensity to being food insecure. Our results show that compared to those households whose heads have agriculture as their main activity, households whose heads are not engaged in agricultural activities or engaged in other activities are less likely to be food insecurity by 19 and 27 percent; respectively. This suggeststhat agriculture may not necessarily be the only mechanism to lift rural household from food insecurity.

Surprisingly, access to extension appeared to increase instead of decreasing the probability of being food insecure, while access to credit although not significant had the expected negative sign on food insecurity. Our results on the access to extension services deserve careful interpretation. We do not imply that accessing extension services is a bad thing, instead, they highlight the limited coverage of extension services, targeting only 13 percent of households of which 29 percent only are food insecure. Also, a positive correlation between access to extension and food insecurity, could suggest that the access to those services may be restrictive or unavailable in real time when needed or in low quality.

We use remoteness to measure access to transportation services and found that households living in accessible villages are 5 percent less likely to be food insecure than their counterparts in less accessible villages, suggesting the importance of investing in the transportation sector as a crucial intervention to tackle poverty. 
Table 2: Determinants of change in food insecurity between 2008 and 2011, Random -Effects Models

\begin{tabular}{|c|c|c|c|}
\hline Variables & Probit & Logit & Probit-IV \\
\hline Year $=2011$ & $\begin{array}{c}-0.023 \\
(0.07)\end{array}$ & $\begin{array}{l}0.020 \\
(0.08)\end{array}$ & $\begin{array}{l}0.020 \\
(0.08)\end{array}$ \\
\hline Log of cultivated area per $\mathrm{AE}$ & $\begin{array}{c}-0.096^{*} \\
(0.05)\end{array}$ & $\begin{array}{c}-0.472 * * \\
(0.17)\end{array}$ & $\begin{array}{c}-0.472 * * \\
(0.17)\end{array}$ \\
\hline $\mathrm{HH}$ is tenure insecure $(1=\mathrm{Yes})$ & $\begin{array}{l}0.120 \\
(0.07)\end{array}$ & $\begin{array}{c}0.199 * \\
(0.08)\end{array}$ & $\begin{array}{c}0.199 * \\
(0.08)\end{array}$ \\
\hline Aggregated crop production ( $\log$ ) & $\begin{array}{l}-0.057 \\
(0.04)\end{array}$ & $\begin{array}{c}-0.095^{*} \\
(0.05)\end{array}$ & $\begin{array}{c}-0.095^{*} \\
(0.05)\end{array}$ \\
\hline Male-headed HH (1=yes) & $\begin{array}{c}-0.279 * \\
(0.12)\end{array}$ & $\begin{array}{c}-0.311 * \\
(0.15)\end{array}$ & $\begin{array}{c}-0.311^{*} \\
(0.15)\end{array}$ \\
\hline Females in secondary school (Number) & $\begin{array}{c}-0.034 \\
(0.11)\end{array}$ & $\begin{array}{l}0.158 \\
(0.14)\end{array}$ & $\begin{array}{l}0.158 \\
(0.14)\end{array}$ \\
\hline Males in secondary school (Number) & $\begin{array}{c}-0.177^{*} \\
(0.08)\end{array}$ & $\begin{array}{c}-0.245^{*} \\
(0.10)\end{array}$ & $\begin{array}{c}-0.245^{*} \\
(0.10)\end{array}$ \\
\hline Dependence ratio & $\begin{array}{c}0.086^{*} \\
(0.03)\end{array}$ & $\begin{array}{c}0.082^{*} \\
(0.04)\end{array}$ & $\begin{array}{c}0.082 * \\
(0.04)\end{array}$ \\
\hline Agriculture as second activity of the head $(1=$ Yes $)(b)$ & $\begin{array}{l}0.043 \\
(0.11)\end{array}$ & $\begin{array}{l}-0.083 \\
(0.13)\end{array}$ & $\begin{array}{l}-0.083 \\
(0.13)\end{array}$ \\
\hline Head not engage in agricultural activities $(1=$ Yes $)(b)$ & $\begin{array}{c}-0.184 * \\
(0.09)\end{array}$ & $\begin{array}{c}-0.184+ \\
(0.10)\end{array}$ & $\begin{array}{c}-0.184 \\
(0.10)\end{array}$ \\
\hline Head engaged in other activities $(1=$ Yes $)(b)$ & $\begin{array}{r}-0.271 \\
(0.15)\end{array}$ & $\begin{array}{l}-0.152 \\
(0.16)\end{array}$ & $\begin{array}{l}-0.152 \\
(0.16)\end{array}$ \\
\hline Access to extension services $(1=$ Yes $)$ & $\begin{array}{c}0.316 * * \\
(0.10)\end{array}$ & $\begin{array}{c}0.350 * * \\
(0.12)\end{array}$ & $\begin{array}{c}0.350 * * \\
(0.12)\end{array}$ \\
\hline $\mathrm{HH}$ received credit ( $1=$ Yes $)$ & $\begin{array}{c}-0.186 \\
(0.20)\end{array}$ & $\begin{array}{c}-0.088 \\
(0.21)\end{array}$ & $\begin{array}{c}-0.088 \\
(0.21)\end{array}$ \\
\hline Total Tropical livestock units & $\begin{array}{l}-0.035 \\
(0.02)\end{array}$ & $\begin{array}{l}-0.006 \\
(0.02)\end{array}$ & $\begin{array}{l}-0.006 \\
(0.02)\end{array}$ \\
\hline HH owns radio (1=Yes) & $\begin{array}{l}-0.130 \\
(0.08)\end{array}$ & $\begin{array}{l}-0.184 \\
(0.10)\end{array}$ & $\begin{array}{l}-0.184 \\
(0.10)\end{array}$ \\
\hline HH purchased grain maize in the 30 days ( $1=$ Yes) & $\begin{array}{l}0.222 * \\
(0.09)\end{array}$ & $\begin{array}{l}0.216^{*} \\
(0.11)\end{array}$ & $\begin{array}{r}0.216^{*} \\
(0.11)\end{array}$ \\
\hline HH purchased cassava in the last 30 days $(1=$ Yes) & $\begin{array}{l}-0.196 \\
(0.12)\end{array}$ & $\begin{array}{c}-0.367 * * \\
(0.14)\end{array}$ & $\begin{array}{c}-0.367 * * \\
(0.14)\end{array}$ \\
\hline HH has housing with good walls ( $1=$ Yes) & $\begin{array}{l}-0.194 \\
(0.15)\end{array}$ & $\begin{array}{c}-0.360^{*} \\
(0.18)\end{array}$ & $\begin{array}{c}-0.360^{*} \\
(0.18)\end{array}$ \\
\hline $\begin{array}{l}\text { Meals taken by the } \mathrm{HH} \text { during hungry season } \\
\text { (Number) }\end{array}$ & $\begin{array}{c}-0.503 * * \\
(0.07)\end{array}$ & $\begin{array}{c}-0.578 * * \\
(0.09)\end{array}$ & $\begin{array}{c}-0.578 * * \\
(0.09)\end{array}$ \\
\hline Reserves of the most important staples (months) & $\begin{array}{c}-0.119^{* *} \\
(0.01)\end{array}$ & $\begin{array}{c}-0.112^{* *} \\
(0.01)\end{array}$ & $\begin{array}{c}-0.112^{* *} \\
(0.01)\end{array}$ \\
\hline HH Net income per AE (Log) & $\begin{array}{l}-0.049 \\
(0.03)\end{array}$ & $\begin{array}{c}-0.059 * \\
(0.03)\end{array}$ & $\begin{array}{c}-0.059^{*} \\
(0.03)\end{array}$ \\
\hline $\mathrm{HH}$ leaves in non-remote village ( $1=$ Yes) & $\begin{array}{r}-0.060 \\
(0.08) \\
\end{array}$ & $\begin{array}{c}-0.183^{*} \\
(0.09)\end{array}$ & $\begin{array}{c}-0.183^{*} \\
(0.09)\end{array}$ \\
\hline $\begin{array}{l}\text { Observations } \\
\text { rho } \\
\text { Likelihood ratio test of rho }=0 \text { (p-value) } \\
\text { Wald test of rho }=0\end{array}$ & $\begin{array}{l}2,191 \\
0.035 \\
0.320\end{array}$ & $\begin{array}{l}2,191 \\
0.059 \\
0.187\end{array}$ & $\begin{array}{c}2,191 \\
-0.251 \\
0.2246\end{array}$ \\
\hline
\end{tabular}

Marginal effects; standard errors in parentheses; District FE included; HH: household; * at 5\%, ** at 1\%;

(a) Reference is male non-widow head; (b) Reference is head engaged in agriculture as primary activity; (c) Reference is maize; (d) Reference is better than 3 years ago; (e) reference is Yes

Source: Author's computation from TIA 2008 and Partial Panel 2011 
Due to data limitations on food prices, we incorporated the effect of food prices on food security through two mechanisms: coping strategies and food purchases (regular and during the hungry season). Given that households in rural areas are net buyers, we hypothesized that households would have difficulties in purchasing food during the study period as food prices were high, leading to purchasing low nutrient quality or cheap foods. Our results show that households that purchased maize increased their likelihood of being food insecure by 5 percent than those that did not. On the other hand, those that purchased cassava 30 days before the interview had led to a reduction in food insecurity by 8 percent. Note that Maize is the main staple food and observed large price increase during the cropping season 2007/08. According to MSU (2011), maize was being sold at 100 percent of previous year price of 2-3 MZN/Kg).

Establishing direct causality of food insecurity and its drivers is an important empirical challenge. In empirical applications, direct causality is dependent on finding suitable instruments of potential endogenous explanatory variables. Recognizing the difficulties of finding instruments for our explanatory variables, we have attempted to address the endogeneity of landholdings on food security by estimating an instrumental Probit model using inherited land as its instrument.

As reported in Table 2, we failed to reject the null hypothesis that landholdings are exogenous to food insecurity. The validity of the over-identification instruments was granted by the rejection of the null hypothesis that at least one instrument is not valid, leading to the conclusion that the over-identification restriction is valid.

\subsection{Factors explaining exiting/entering into food insecurity trap}

In the attempt of assessing factors associated with food security change over time, in addition to panel estimation discussed above, we estimated three Probit models to compare the factors associated with the likelihood of becoming food insecure, escaping food insecurity, and becoming self-sufficient.

Results in Table 3 corroborate with our discussion above, and show that an increase food supply through crop production, male-headship and adoption of improved agricultural technologies (e.g pesticides), use of animal traction, hiring farm labor as well ashead engagement in income generating activities other than agriculture, the ownership of farmassets, the number of adult members, the age of the household head, and the increase in number of months with food reserves of the main staple food decreases the chance of being food insecure and increase chance of escaping food insecurity.

Surprisingly, the lack of food reserves from own production as a result of lost production or low production are positively correlated with escaping food insecurity compared to those that had food reserves from own production, perhaps because these households do not rely on other sources to acquire food. Results also confirm that households with large number of dependent members are more likely to be in food insecurity trap.

Our results support the idea that food insecurity may not necessarily result of failure in agriculture in rural as indicated by the fact that households belonging to farming sector appear to be more likely to being food insecure. Our estimates show that the marginal effect of agricultureas as econdary activity, and other activities besides agriculture increases the chance of escaping food insecurity by 0.23 and 0.23 percent; respectively. On the other hand, household heads that are engaged in agricultural activities as secondary activities and those not engaged in agricultural activities decrease their chance of becoming food insecure by 9 and 7 percent; respectively compared to those engaged in agriculture as the main activity. Again, this indicates the important of non-farm activities in reducing food insecurity among the rural households.

Given that, the measure of food security is derived from a self-reported assessment of food security status of the household; we performed a robustness check using a more objective measure, the number of food reserves 12 months before the interview. We then classified household into self-sufficient if had 7 or more months of food reserves of the main staple food and assigned a value of one and zero those that did not have more than six months of food reserves. Results are presented in the last column of Table 3. Assuming that self-sufficient households are likely to escape food insecurity, we expect the results of the last column to mimic those of the first column in Table 3. As expected, results are consistent with our earlier findings that: (i) the use of pesticides, hiring seasonal farm labor, use of quality land, and increased food supply increases the likelihood of food self-sufficiency of the households; (ii) concerning food reserves and access, results show that households with limited food reserves due to not growing crops and production loss increased their likelihood of being self-sufficient through purchasing cheap staple food such as maize; and (iii) surprisingly, increased household members with selfemployment increase the chance of the household being food self-sufficient.

The surprising result of our study is that cultivated 
land, remoteness, and household income per AE are not significant drivers for moving from the persistent food insecure to food secure states no is to increase food self-sufficiency. These results suggest that there is an evidence of the effect of landholdings in reducing the likelihood of being food insecure, such effect is still minimal to distinguish between chronic food insecure and those escaping poverty. We expect that if farmers can significantly increase their landholding sizes and increase incomes or access to non-farm employment opportunities, they are likely to escape from food insecurity. The key finding of our study is that land expansion is not an important driver of food security, but the land quality is. This highlights the importance of intensification instead of extensification to fight food insecurity in the rural Mozambique.

Table 3: Factors explaining the likelihood of escaping or becoming food insecurity

\begin{tabular}{|c|c|c|c|}
\hline \multirow[t]{2}{*}{ Variables } & \multicolumn{3}{|c|}{ Probability that $[\ldots]$} \\
\hline & $\begin{array}{l}\text { HH Escaped } \\
\text { food insecurity }\end{array}$ & $\begin{array}{l}\text { HH Became } \\
\text { food insecure }\end{array}$ & $\begin{array}{l}\text { HH is self- } \\
\text { sufficient }\end{array}$ \\
\hline \multirow[t]{2}{*}{ HH lives in non-remote village ( $1=$ Yes $)$} & 0.014 & -0.031 & 0.033 \\
\hline & $(0.16)$ & $(-0.88)$ & $(1.02)$ \\
\hline \multirow[t]{2}{*}{ Cultivated land per AE (Log) } & 0.182 & -0.018 & 0.043 \\
\hline & $(1.20)$ & $(-0.28)$ & $(0.85)$ \\
\hline \multirow[t]{2}{*}{ Male-headed HH (1=Yes) } & $0.345^{* *}$ & -0.014 & 0.054 \\
\hline & $(2.75)$ & $(-0.26)$ & $(1.05)$ \\
\hline \multirow[t]{2}{*}{ Head's age (years) } & -0.000 & $-0.003^{*}$ & 0.002 \\
\hline & $(-0.06)$ & $(-2.31)$ & (1.64) \\
\hline \multirow[t]{2}{*}{ People aged $15-59$ years (number) } & -0.032 & $0.037^{*}$ & -0.007 \\
\hline & $(-0.98)$ & $(2.45)$ & $(-0.51)$ \\
\hline \multirow[t]{2}{*}{ People with self-employment (number) } & -0.039 & 0.002 & $-0.025^{+}$ \\
\hline & $(-1.06)$ & $(0.13)$ & $(-1.66)$ \\
\hline \multirow[t]{2}{*}{ HH has good land quality (1=Yes) } & $0.258^{* *}$ & -0.005 & $0.074^{*}$ \\
\hline & $(4.17)$ & $(-0.15)$ & $(2.40)$ \\
\hline \multirow[t]{2}{*}{ HH used pesticide ( $1=$ Yes $)$} & $0.253^{* *}$ & $-0.113^{* *}$ & $0.168^{*}$ \\
\hline & $(4.38)$ & $(-2.66)$ & $(2.17)$ \\
\hline \multirow[t]{2}{*}{ HH hired permanent labor $(1=$ Yes $)$} & $0.197^{+}$ & 0.027 & -0.090 \\
\hline & $(1.85)$ & $(0.31)$ & $(-1.38)$ \\
\hline \multirow[t]{2}{*}{ HH hired seasonal labor ( $1=$ Yes $)$} & $0.157^{+}$ & $-0.084^{* *}$ & $0.079^{*}$ \\
\hline & $(1.76)$ & $(-2.67)$ & $(2.55)$ \\
\hline \multirow[t]{2}{*}{ HH use animal traction ( $1=$ Yes $)$} & $0.157^{+}$ & $-0.065^{+}$ & 0.068 \\
\hline & $(1.84)$ & $(-1.68)$ & $(1.49)$ \\
\hline \multirow[t]{2}{*}{ Agriculture as second activity of the head (1=yes)(b) } & $0.226^{* *}$ & $-0.087^{*}$ & 0.023 \\
\hline & $(2.97)$ & $(-2.46)$ & $(0.53)$ \\
\hline \multirow[t]{2}{*}{ Head not engage in agricultural activities $(1=y e s)(b)$} & -0.061 & $-0.068^{*}$ & 0.004 \\
\hline & $(-0.59)$ & $(-1.97)$ & $(0.12)$ \\
\hline \multirow[t]{2}{*}{ Head engaged in other activities $(1=y e s)(b)$} & $0.304^{* *}$ & -0.028 & 0.066 \\
\hline & $(7.53)$ & $(-0.46)$ & $(1.22)$ \\
\hline \multirow[t]{2}{*}{ Belongs to farmer organization ( $1=$ Yes) } & -0.192 & $0.132^{*}$ & 0.020 \\
\hline & $(-1.35)$ & $(2.19)$ & $(0.47)$ \\
\hline \multirow[t]{2}{*}{ Purchased maize grain 30 days before the interview ( $1=$ Yes) } & 0.045 & -0.056 & $0.077^{*}$ \\
\hline & $(0.50)$ & $(-1.38)$ & $(2.16)$ \\
\hline \multirow[t]{2}{*}{ No, because did not grow crops (a) } & -0.208 & 0.006 & $0.125^{*}$ \\
\hline & $(-1.03)$ & $(0.06)$ & $(2.01)$ \\
\hline \multirow[t]{2}{*}{ No, because lost production (a) } & $0.200^{*}$ & 0.237 & $0.207^{* *}$ \\
\hline & $(2.20)$ & $(1.49)$ & $(3.58)$ \\
\hline \multirow[t]{2}{*}{ No, because had low production (a) } & $0.193^{*}$ & 0.061 & -0.009 \\
\hline & $(2.42)$ & $(0.61)$ & $(-0.17)$ \\
\hline \multirow[t]{2}{*}{ HH has housing with good walls ( $1=$ Yes) } & $0.296^{* *}$ & -0.035 & 0.002 \\
\hline & $(6.94)$ & $(-0.73)$ & $(0.05)$ \\
\hline \multirow[t]{2}{*}{ Food reserves (\# months) } & 0.004 & $0.010^{+}$ & $0.075^{* *}$ \\
\hline & $(0.29)$ & $(1.84)$ & $(14.60)$ \\
\hline \multirow[t]{2}{*}{ dependency ratio } & $-0.052^{+}$ & 0.026 & -0.014 \\
\hline & $(-1.71)$ & $(1.57)$ & $(-0.94)$ \\
\hline
\end{tabular}




\begin{tabular}{lccc} 
HH Net income per AE $(\log )$ & -0.006 & -0.001 & 0.013 \\
& $(-0.26)$ & $(-0.11)$ & $(1.32)$ \\
Total crop production $(\log )$ & $0.095^{*}$ & -0.020 & $0.030^{*}$ \\
& $(2.15)$ & $(-1.12)$ & $(2.00)$ \\
\hline Observations & 481 & 1,419 & 1,945 \\
Pseudo R-square & 0.326 & 0.137 & 0.270 \\
Percent predicted correctly & 0.73 & 0.16 & 0.60 \\
\hline
\end{tabular}

Marginal effects; t statistics in parentheses; + at 10\%, * at 5\%, ** at 1\%, (a) reference is $\mathrm{HH}$ have food reserves from own production; (b) reference is head engaged in agriculture as primary activity

Source: Author's computation from TIA 2008 and Partial Panel 2011

\section{Conclusions and Policy Implications}

The general objective of this study is to assess household food security trends and its drivers, specifically to determine the extent landholdings have influenced food security dynamics in rural Northern-Central Mozambique.

The main finding of this study is that although food security level has been stable over the study period, the initial landholdings, agricultural production, rural non-farm activities, establishment of food reserves, food availability, assets, and access to non-farm income opportunities and transportation have influenced food security level of the rural families. Most importantly, we conclude that food insecurity in rural Mozambique is not necessarily resulting from the failure in agriculture but by a combined and systematic socioeconomic failure.

The policy implications from this study include: implementing land reforms to encourage land expansion and intensification through promoting agricultural technologies, rural financial services and microcredit, risk coping strategies through establishment development of drought resistant crop varieties; small and medium enterprises, vocational training programs in employable skills, facilitating access to input and output markets through improving and expanding infrastructures; implementing land reforms to assure tenure security to ensure that the cash-constrained households have access to these services; providing public services (e.g. education and employment); and investing in physical infrastructures (roads and transports).

\section{Refernces:}

[1] Garrett, J.L., \& Ruel, M.T. (1999). Are Determinants of Rural and Urban Food Security and Nutritional Status Different? Some Insights from Mozambique. World Development, 27(11), 1955-1975. http://doi.org/10.1016/S0305-750X(99)00091-1

[2] Mabiso, A., Cunguara, B., \& Benfica, R. (2014). Food (In)security and its drivers: insights from trends and opportunities in rural Mozambique. Food Security, 6(5), 649-670. http://doi.org/10.1007/s12571-014-0381-1

[3] World Bank (2014). World Development Indicators: Agricultural Production and Productivity. (Available at http://data.worldbank.org, accessed 17 November 2014).
[4] IFPRI (2013). 2013 Global Hunger Index. The Challenge of Hunger: Building Resilience to Achieve Food and Nutrition Security.

[5] UNDP (2014). 2014 Human and Development Statistical Tables. Available at http//:hdr.undp.org/data Accessed on January $17,2015$.

[6] WFP (2012). Country Programme Mozambique 200286 (2012-2015). (Available at http//:wfp.org/eb, Accessed on January 17, 2015)

[7] Tschirley, D.L, \&Weber, M.T. (1994). Food security strategies under extremely adverse conditions: the determinants of household income and consumption in rural Mozambique. World Development, 42 (2), 159-173.

[8] Chung, K. (2012). An Introduction to NutritionAgriculture Linkages. Directorate of Economics,Ministry of Agriculture. Research Report 72E, February 2012.

[9] Burgess, R. (2001). Land Welfare: Theory and Evidence from China. Working Paper. Department of Economics and STICERD. London School of Economics, London.

[10] Valente, C. (2009). The Food In(security) Impact of Land Redistribution in South Africa: Micro econometric Evidence from National Data. World development 37 (9), 1540-1533.

[11] Wooldridge, J.M. (2002). Econometric Analysis of Cross Section and Panel Data. Cambridge, MA: MIT Press.

[12] Pitoro, R. (2016). The Challenges and Effects of Agrarian Reform in Africa: Evidence from Rural Mozambique. A Dissertation Submitted to Michigan State University in partial fulfillment of the requirements for the degree of Community Sustainability - Doctor of Philosophy. March 2016.

[13] United Nations (1975). Report of the World Food Conference, Rome 5-16 November 1974. New York: United Nations.

[14] Sen, A.(1981). Poverty and famines: an essay on entitlement and deprivation. Oxford: Oxford University Press.

[15] FAO (1983). World Food Security: AReappraisal of theConcepts and Approaches. Director General's Report. Rome: FAO.

[16] FAO (1996). Rome Declaration on World Food Security. World Food Summit, Rome.

[17] FAO (2002). International Scientific Symposium on Measurement and Assessment of Food Deprivation and Undernutrition. Executive Summary. June 26-28. Rome: FAO/Food Insecurity and Vulnerability Information and Mapping System

[18] Maxwell, D., \& Wiebe, K. (1998). Land Tenure and Food Security; A Review of Concepts, Evidence, and Methods. Research Paper No.129. January 1998. Land Tenure Center. University of Wisconsin, Madison.

[19] USAID (2010). Land Tenure, Property Rights, and Food security. Emerging Implications for USG Policies and Programming Property Rights and Resource Governance Briefing Paper \#1. USAID Issue Brief. UNDP (2015). Human Development Report 2015. Work for Human Development. United Nations Development Programme, New York, USA. 
[20] Feleke, S., Kilmer,R.L.,\& Gladwin, C. (2005), Determinants of food security in Southern Ethiopia. Agricultural Economics, 33, 351-363.

[21] Ministry of Planning and Development. (2010). Poverty and Well-being in Mozambique: The Thrid National Assessment. National Directorate of Studies and Policy Analysis. October 2010.

[22] Nyyssölä, M., \& Pirttilä, J., \& Sandström, S. (2012). Helping Poor Farmers to Help Themselves. Evidence from a Group-Based Aid Project in Mozambique. Working Paper No. 2012/88. October 2012.

[23] Maredia, M., Pitoro, R., Songqing, J., Payongayong, E., \& Schultink,G.(2012). Impact Evaluation of site-specific Activities under the Land Tenure Services Project: Report of the Baseline Survey Conducted in Two Urban Areas in Northern Mozambique. Report Submitted by Michigan State University to Millennium ChallengeCorporation. October 4, 2012

[24] Barrett, C. (2002). Food security and food assistance programs. In B. L. Garner and G. C. Rausser, eds. Handbook of Agricultural Economics. Amsterdam: Elsevier Science.

[25] Devereux, S. \& Maxwell, S. (2001). Food Security in SubSaharan Africa. London: Intermediate Technology Development Group Publishing.

[26] Misselhorn, A. (2005). What drives food insecurity in southern Africa? A meta-analysis of household economy studies. Global Environmental Change 15: 33-43.

[27] Ziervogel,G., Nyong,A., Osman, B., Conde,C.,Cortés, C.,\& Downing, T.(2006). Climate variability and change: implications for household food security. AIACC Working
Paper No. 20. Assessments of Impacts and Adaptations to Climate Change (AIACC).

[28] Ellis, F.(1998). Household strategies and rural livelihood diversification. The Journal of Development Studies 35 (1): $1-38$.

[29] Grootaert, C. (1997). Social Capital: The Missing Link? In World Bank, Expanding the Measure of Wealth: Indicators of Environmentally SustainableDevelopment. Washington, D.C

[30] Geda, A., Jong,N., Kimenyi,M.,\& Mwabu, G.( 2005) Determinants of Poverty in Kenya: A Household Level Analysis. Department ofEconomics Working Paper Series No. 2005-44, University of Connecticut, Storrs, Connecticut (http://www.econ.uconn.edu/working/2005-44.pdf).

[31] Walker,T.,Tschirley, D.L., Low. J.,Tanque, M.,Boughton, D.,Payongayong, E.,\&Weber, M.(2004). Determinants of Rural Income in Mozambique in 2001-2002.Research Report No 57 E. May 2004 (CDIE Reference number PNADH-865).

[32] Boughton, D., Mather, D., Tschirley, D., Walker, T., Cunguara, B., \& Payongayong, E. (2006). Changes in Rural Household Income Patterns in Mozambique, 19962002, and Implications for Agriculture's Contribution to Poverty Reduction. RP61E. December 2006.

[33] Boughton, D., Mather, D., Barrett,C., Benfica, R., Abdula, D., Tschirley, D. \& Cunguara, B.(2007). Market participation by rural households in a low-income country: an asset-based approach applied to Mozambique. Faith and Economics, 50, 64-101. 